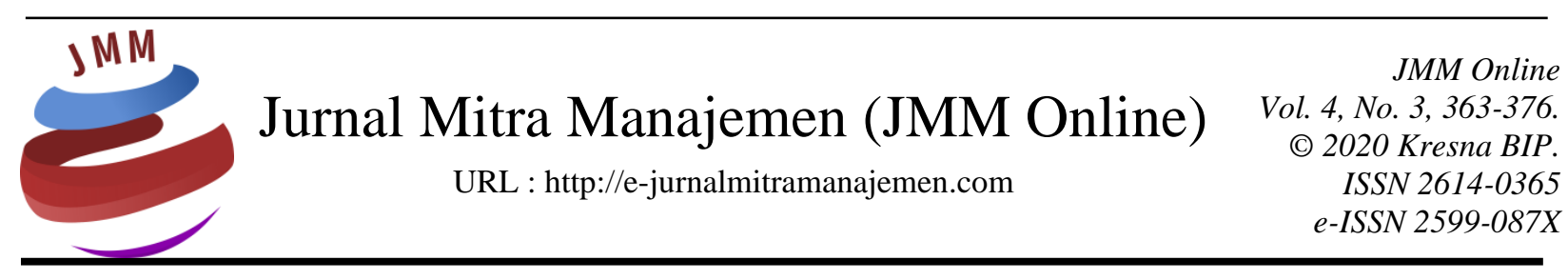

\title{
PERAN KEMAMPUAN KEUANGAN SEBAGAI MEDIATOR PENDIDIKAN KEUANGAN DAN KEPUASAN KEUANGAN (STUDI KASUS PADA USIA PRODUKTIF D.I YOGYAKARTA)
}

\author{
Eni Rahmawati ${ }^{1)}$, Palti MT Sitorus ${ }^{2)}$ \\ Universitas Telkom
}

INFORMASI ARTIKEL

Dikirim : 09 Maret 2020

Revisi pertama : 20 Maret 2020

Diterima : 25 Maret 2020

Tersedia online : 30 Maret 2020

Kata Kunci : Pendidikan Keuangan, Kepuasan Keuangan, Kemampuan Keuangan, Usia Produktif

Email : rahmaeny9@gmail.com ${ }^{1)}$, paltisitorus@telkomuniversity.ac.id ${ }^{2))}$

\section{ABSTRAK}

Pendidikan keuangan mempunyai banyak manfaat untuk kesejahteraan masyarakat dalam mengatur keuangannya. Dengan masih rendahnya pendidikan keuangan pada usia produktif, peran kemampuan keuangan sebagai mediator pendidikan keuangan perlu mendapat perhatian. Pada penelitian ini akan diteliti mengenai peran kemampuan keuangan sebagai mediator pendidikan keuangan dan kepuasan keuangan. Metode pengumpulan data dilakukan dengan menyebar kuesioner secara langsung kepada masyarakat usia produktif Daerah Istimewa Yogyakrta dengan jumlah 400 responden. Penelitian ini menggunakan teori Baron dan Kenny, kemudian menggunakan Sobel Z test untuk mengetahui pengaruh mediasi kemampuan keuangan dalam hubungan antara pendidikan keuangan dan kepuasan keuangan. Hasil dalam penelitian ini yaitu pendidikan keuangan mempunyai pengaruh yang signifikan terhadap kemampuan keuangan, kemampuan keuangan mempunyai pengaruh yang signifikan terhadap kepuasan keuangan, dan kemampuan keuangan secara parsial terbukti bahwa memediasi hubungan antara pendidikan keuangan dan kepuasan keuangan. 


\section{PENDAHULUAN \\ Latar Belakang}

Yushita (2017) mengemukakan bahwa dengan semakin pesat pembangunan dan pertumbuhan ekonomi saat ini, pendidikan keuangan mempunyai peran penting untuk masyarakat luas agar masyarakat dapat menentukan produk dan jasa layanan keuangan yang sesuai dengan kebutuhan masyarakat serta mengetahui risiko, hak dan kewajibannya. Dengan peningkatan keahlian pada keungan menciptakan kesadaran akan risiko yang diambil dalam menentukan keputusan keuangan yang mengakibatkan hasil keputusan yang baik dan juga apabila memahami keuangan dengan baik akan menghasilkan keuntungan finansial secara mandiri. Pendidikan keuangan dapat meningkatkan pemahaman masyarakat terhadap cara pandang yang bijak terkait pengelolaan keuangan berdasarkan pada skala prioritas yang dibutuhkannya, bukan terhadap apa yang mereka inginkan (Kompasiana, 2019).

Menurut Herawati (2015) literasi keuangan merupakan kemampuan dan keahlian seseorang dalam mengelola keuangannya untuk masa kini sampai masa yang akan datang. Berdasarkan hasil survey dari Otoritas Jasa Keuangan indeks literasi keuangan masyarakat Indonesia mengalami peningkatan dari 21,8\% pada tahun 2013 menjadi $29,7 \%$ pada tahun 2016 dan juga hanya 13 provinsi dari seluruh provinsi di wilayah Indonesia yang memiliki tingkat literasi keuangan di atas rata-rata nasional.

Persentase indeks literasi keuangan per provinsi dapat diketahui bahwa Daerah Istimewa Yogyakarta memiliki indeks literasi keuangan yang tinggi yaitu sebesar $38,5 \%$, hal ini membuat Daerah Istimewa Yogyakarta menjadi provinsi ke-2 yang mempunyai indeks literasi tinggi setelah DKI Jakarta. Jumlah penduduk usia produktif 15-55 tahun di D.I Yogyakarta tahun 2018 yaitu sebanyak 2.445.000 jiwa.

Berdasarkan dari data Bank Indonesia bahwa rata-rata pendapatan masyarakat Indonesia sebanyak 67,69 persen digunakan untuk kegiatan konsumtif, kemudian 13,73 persen untuk pinjaman/cicilan dan sebesar 18,58 persen untuk kegiatan menabung. Selain masih rendahnya minat menabung, gaya hidup yang tinggi membuat seseorang untuk berhutang (Deil, 2018). Salah satu sistem berhutang yaitu menggunakan kartu kredit. Mudahnya berbelanja dengan kartu kredit tanpa batasan membuat hutang semakin menumpuk dan jika telat membayar maka hutang akan terus bertambah (Sepulsa.com, 2019). Berbagai kemudahan yang ditawarkan pada penggunaan kartu kredit membuat seseorang lebih konsumtif (Primadhyta, 2018). Dengan memiliki kemampuan keuangan yang baik dalam mengelola keuangan dan melakukan berbagai hal yang dibutuhkan di dalam keuangan, maka keuangan akan tepat sasaran (Sari, 2019). Sehingga kepuasan keuangan akan tercapai. Kepuasan keuangan adalah kondisi keuangan yang sehat secara finansial, sehingga merasa bahagia dan bebas dari rasa khawatir terhadap kondisi keuangan yang dimiliki (Chandra dan Memarista, 2015). Inti pembahasan dari penelitian ini yaitu untuk mengetahui peran kemampuan keuangan sebagai mediator pendidikan keuangan dan kepuasan keuangan (studi kasus pada usia produktif D.I Yogyakarta). 


\section{Rumusan Masalah}

Berdasarkan latar belakang dan perumusan masalah di atas, maka pertanyaan penilitian ini adalah:

1. Apakah pendidikan keuangan mempunyai pengaruh yang signifikan terhadap kemampuan keuangan?

2. Apakah kemampuan mempunyai pengaruh yang signifikan pada kepuasan keuangan?

3. Apakah pendidikan keuangan mempunyai pengaruh yang signifikan terhadap kepuasan keuangan dengan kemampuan keuangan dan tanpa kemampuan keuangan sebagai variabel mediasi?

\section{Tujuan Penelitian}

Berdasarkan latar belakang dan rumusan masalah di atas, tujuan penelitian ini adalah sebagai berikut:

1. Untuk mengetahui apakah pendidikan keuangan mempunyai pengaruh yang signifikan terhadap kemampuan keuangan.

2. Untuk mengetahui apakah kemampuan keuangan mempunyai pengaruh yang signifikan terhadap kepuasan keuangan.

3. Untuk mengetahui apakah pendidikan keuangan mempunyai pengaruh yang signifikan terhadap kepuasan keuangan dengan kemampuan keuangan dan tanpa kemampuan keuangan sebagai variabel mediasi.

\section{KAJIAN PUSTAKA \\ Manajemen Keuangan}

Menurut Sujarweni (2017) manajemen keuangan adalah suatu proses perencanaan, pengorganisasia, pengarahan dan pengawasan terhadap sumber daya untuk mencapai tujuan yang telah ditetapkan suatu perusahaan. Sedangkan Manajemen keuangan menurut Anwar (2019:5) adalah suatu disiplin ilmu yang mempelajari tentang pengolahan keuangan perusahaan baik dari pencarian sumber data, pengalokasian dana, maupun pembagian hasil keuntungan perusahaan. Menurut Fahmi (2014:2) manajemen keuangan merupakan penggabungan dari ilmu dan seni yang membahas, mengkaji dan menganalisis tentang bagaimana seorang manajer keuangan dengan mempergunakan seluruh sumberdaya untuk mencari dana, mengelola dana, dan membagi dana dengan tujuan mampu memberikan profit atau kemakmuran bagi para pemegang saham dan suistainability (keberlanjutan) usaha bagi perusahaan.

Keuangan adalah suatu aktivitas yang berhubungan dengan pemerolehan dan pengelolaan dana secara efektif dan efisien sesuai dengan tujuan perusahaan secara menyeluruh (Sujarweni, 2017). Menurut McMenamin (2012) manajemen keuangan adalah analisis tentang situasi keuangan, membuat keputusan keuangan, menetapkan tujuan keuangan dan merumuskan rencana keuangan yang telah ditetapkan. Oleh karena itu, dapat disimpulkan bahwa manajemen keuangan merupakan suatu proses perencanaan, pengorganisasian, pengarahan dan pengawasan terhadap rencana yang sudah ditetapkan oleh perusahaan untuk mengasilkan profit dan keberlangsungan usaha perusahaan. 


\section{Pendidikan Keuangan}

Pendidikan keuangan adalah proses membangun pengetahuan, keterampilan dan sikap untuk sadar akan keuangan dalam praktek pengelolaan keuangan yang baik dengan mendapatkan, membelanjakan, menabung, meminjam dan berinvestasi (Cohen dan Nelson, 2011). Menurut Xiao dan Porto (2017) dalam studinya mengemukakan bahwa seseorang yang menerima pendidikan keuangan akan meningkatkan kemampuan keuangan mereka untuk mengelola uang mereka dan melakukan keuangan dengan baik dari pada rekan mereka yang tidak menerima pendidikan keuangan. Pendidikan keuangan mempunyai dampak positif pada keuangan dengan meningkatkan pengetahuan keuangan, mendorong perilaku keuangan yang positif dan meningkatkan kepercayaan dalam kemampuan keuangan (Xiao dan O'Neill, 2016).

Menurut Halim dan Astuti (2015) pendidikan keuangan merupakan kemampuan seseorang untuk memahami, mengelola keuangan untuk membuat keputusan keuangan dengan baik dan terhindar dari risiko keuangan. Menurut (Sigo et $a l$, 2018) dalam penelitiannya mengemukakan bahwa pendidikan keuangan perlu diajarkan sejak kecil dari keluarga karena dapat memberikan bekal kepada anak agar mampu mengelola keuangannya dengan lebih baik dikemudian hari. Pendidikan keuangan merupakan proses membangun keuangan dalam kehidupan seseorang yang dapat meningkatkan literasi keuangan dan kesejahteraan seseorang dalam keuangan (Yoshino et al, 2015). Menurut Rapih (2016) pendidikan keuangan sangat bermanfaat bagi kehidupan manusia, yang mana ketepatan ketepatan pengambilan keputusan keuangan sangat menentukan pada kesejahteraan manusia dimasa yang akan datang, maka perlu dibekali pendidikan keuangan yang baik dan terencana. Sehingga pendidikan keuangan merupakan pengetahuan seseorang dalam memahami, mengelola keuangannya agar tehindar dari risiko keuangan yang dapat meningkatkan kemampuan seseorang dalam mengambil keputusan sehingga tercipta kepuasan keuangan.

\section{Kepuasan Keuangan}

Menurut Xiao et al. (2014) dalam studinya menemukan bahwa kepuasan keuangan dengan menjelajah kemampuan keuangan merupakan sebuah variable kebijakan penting yang dapat digunakan untuk membantu meningkatkan kemampuan untuk menjalani kehidupan yang lebih baik. Kepuasan keuangan adalah persepsi individu tentang kecukupan sumber daya keuangan diri individu dalam hidupnya (Hakim et al. 2014). Kepuasan keuangan merupakan rasa puas dalam pendapatan yang diterima dan juga rasa puas terhadap tingkat kesejahteraan keuangan maupun kondisi keuangan yang baik (Sari dan Septyarini, 2018).

Menurut Ahmad et al (2017) untuk meningkatkan kepuasan keuangan individu, keluarga dan komunitas aspek-aspek perilaku sangat dibutuhkan dan pekerja-pekerja muda memiliki peran penting dalam peningkatan perekonomian. Kepuasan keuangan adalah identifikasi yang lebih erat kaitannya dengan pengetahuan keuangan sifat dan sikap individu terhadap keuangan (Mehwish dan Muhammad, 2016). Praktik keuangan dalam kehidupan sehari-hari mempunyai peran penting terhadap kepuasan keuangan seseorang (Hassan et al, 2019). 


\section{Kemampuan Keuangan}

Kemampuan keuangan menurut Xiao dan Porto (2017) kemampuan keuangan didefinisikan sebagai kemampuan untuk menggunakan pengetahuan keuangan dasar dan terlibat dalam perilaku keuangan yang diinginkan untuk mencapai kesejahteraan keuangan. Menurut Xiao dan O'Neill (2016) kemampuan keuangan harus menyiratkan tingkat pengetahuan keuangan dan kinerja perilaku yang diinginkan keuangan untuk mencapai kesejahteraan keuangan.

Kemampuan keuangan adalah bagaimana kita memiliki kendali dan pengaruh kuat pada diri kita termasuk perilaku keuangan sehingga berdampak pada tabungan dan pensiun (Cobb-Clark et al, 2016). Pentingnya penyusunan skala prioritas kebutuhan untuk menghindari perilaku konsumsi yang tidak rasional (perilaku konsumtif) dan harus memperhatikan kemampuan keuangan yang dimiliki, agar tidak terjadi pengeluaran yang lebih besar dari pada pendapatan (Septiana, 2017). Oleh karena itu kemampuan keuangan merupakan kemampuan seseorang dalam menggunakan pengetahuan atau pendidikan keuangan dalam bertindak dalam keuangan untuk mencapai kepuasan keuangan atau kesejahteraan keuangan

\section{Hubungan Antara Pendidikan Keuangan, Kepuasan Keuangan Melalui Kemampuan Keuangan}

Tujuan pada penelitian ini yaitu untuk menguji apakah pendidikan keuangan mempengaruhi atau mempunyai kontribusi terhadap kemampuan keuangan yang kemudian berkontribusi terhadap kepuasan keuangan, sehingga penelitian ini menunjukkan bahwa pendidikan keuangan mempunyai hubungan terhadap kepuasan keuangan melalui mediasi kemampuan keuangan secara pengaruh langsung dan tidak langsung dan memberikan banyak manfaat bagi yang menerimanya.

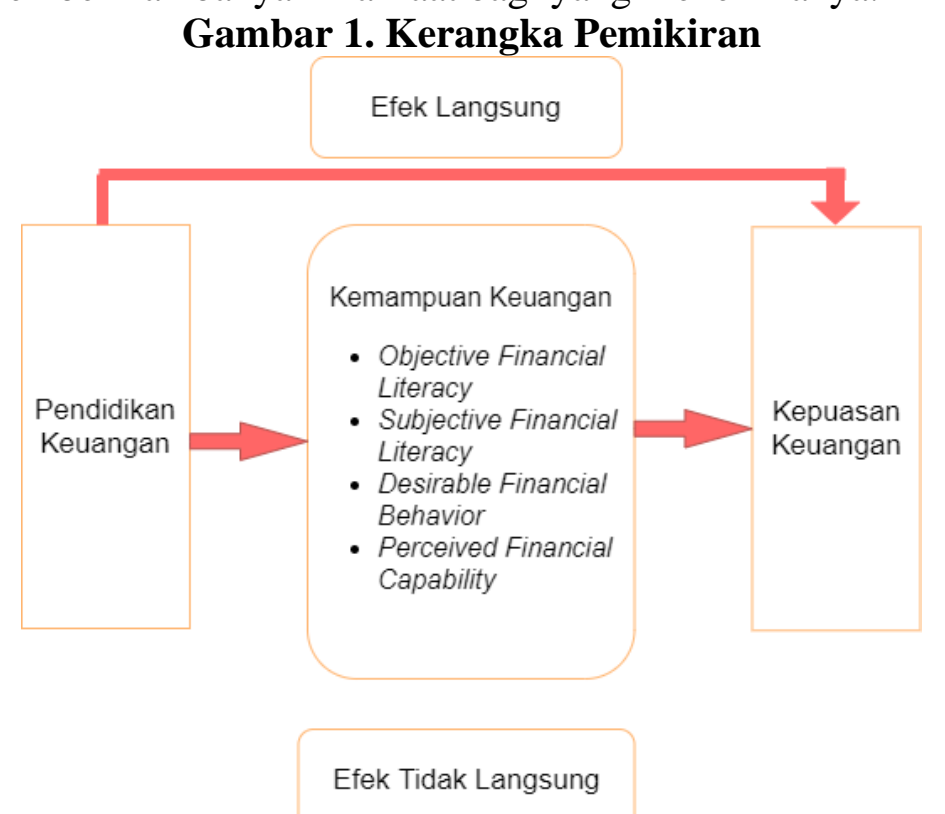

Sumber: Xiao dan Porto, 2017

Eni Rahmawati ${ }^{1)}$, Palti MT Sitorus ${ }^{2)}$ 


\section{Hipotesis Penelitian}

$\mathrm{H}_{1}$ : Pendidikan keuangan mempunyai pengaruh yang signifikan terhadap kemampuan keuangan

$\mathrm{H}_{2}$ : Kemampuan keuangan mempunyai pengaruh yang signifikan terhadap kepuasan keuangan

$\mathrm{H}_{3}$ : Pengaruh pendidikan keuangan terhadap kepuasan keuangan lebih tinggi jika diteliti dengan kemampuan keuangan dibandingkan dengan kemampuan keuangan sebagai variabel mediasi

\section{METODE PENELITIAN Jenis Penelitian}

Metode penelitian yang digunakan penelitian ini adalah metode kuantitatif, yaitu penelitian dengan filsafat positivism dengan menggunakan sampel atau populasi tertentu. Berdasarkan tujuannya yaitu kausal yang mempunyai arti bahwa peneliti ingin mengetahui hubungan sebab-akibat yang terjadi antar variabel. Berdasarkan tipe penyelidikannya penelitian ini merupakan penelitian korelasional, artinya penelitian ini mencari besaran hubungan antar variabel penelitian dengan memperhatikan besaran koefisian korelasi. Berdasarkan keterlibatan penulis, penulis tidak mengintervensi data dan menggunakan unit analisis individu. Berdasarkan waktu pelaksanaan, penelitian ini termasuk dalam cross-section yaitu pengambilan data dilakukan dalam periode waktu tertentu.

\section{Variabel Penelitian}

Variabel dalam penelitian ini terdiri dari variabel bebas (independent variable) yaitu pendidikan keuangan (X), variabel dipengaruhi (dependent variable) yaitu kepuasan keuangan (Y) dan variabel mediasi yaitu kemampuan keuangan (M).

\section{Tempat dan Waktu Penelitian}

Penelitian ini dilakukan pada usia produktif dengan rentang usia 15-55 tahun di Daerah Istimewa Yogyakarta dengan jumlah usia produktif sebanyak 2.445.000 jiwa. Penelitian ini dilakukan dari bulan Oktober 2019 sampai bulan Februari 2020.

\section{Teknik Pengumpulan Data}

Data primer pada penelitian ini diperoleh melalui penyebaran kuesioner kepada masyarakat Yogyakarta. Penelitian ini mengambil sampel sebanyak 400 orang dari jumlah usia produktif Daerah Istimewa Yogyakarta, dan diharapkan dapat mempresentasikan populasi yang ada. Pengukuran ketiga variabel dalam penelitian menggunakan 30 item pertanyaan terkait pendidikan keuangan, kepuasan keuangan dan kemampuan keuangan. Pengambilan sampel menggunakan rumus slovin.

\section{Teknik Analisis Data}

Penelitian ini menggunakan teknik analisis data yaitu analisis deskriptif dan analisis korelasi parametrik person product moment, penelitian deskriptif digunakan untuk mendiskripsikan peran kemampuan keuangan sebagai mediator pendidikan keuangan dan kepuasan keuangan studi kasus pada usia produktif Daerah Istimewa 
Yogyakarta. Korelasi menurut Neolaka (2014 : 127) adalah salah satu teknik pengukuran asosisasi atau hubungan (measures of association). Menurut Neolaka (2014 : 131) syarat korelasi Pearson yaitu: sampel dibagi secara acak, ukuran sampel minimum dipenuhi, data sampel masing-masing variabel terdistribusi normal, dan bentuk regresi linear. Hasil dari perhitungan korelasi tersebut adalah koefisien korelasi. Koefisien korelasi adalah koefisien yang didapat dari pengukuran statistik kovarian atau asosiasi antara dua variabel (Neolaka, 2014 : 129). Penelitian ini juga menggunakan analisis uji normalitas yang digunakan untuk mengatahui apakah data yang ada baik untuk digunakan dan berdistribusi normal dengan menggunakan uji kolmogorov-smirnov. Penelitian ini juga menggunakan uji multikolonieritas yang digunkan untuk pengujian pada data sampel apakah terjadi multikolinearitas atau tidak. Menurut Indrawati (2015 : 190) untuk mendeteksi ada atau tidaknya gejala multikolinearitas didalam model regresi berganda dapat dilihat dari : a. Nilai Variance Inflation Factor (VIF) $<10$ tidak terdapat collinearity. b. Nilai toleransi $>0,1$ tidak terdapat collinearity.

Pertanyaan penelitian pada variabel pendidikan keuangan berjumlah 5 item dengan jawaban "Ya" atau "Tidak", untuk variabel kepuasan keuangan berjumlah 5 item pertanyaan dengan skala yang digunakan 1: sangat tidak setuju sampai 5: sangat setuju. dan untuk variabel kemampuan keuangan terdiri dari 4 sub-variabel yaitu:

Objective financial literacy dengan 6 pertanyaan dan skala yang digunakan sangat tidak setuju sampai 5: sangat setuju.

Subjective financial literacy dengan 5 item pertanyaan dan skala yang digunakan 1: sangat tidak setuju sampai 5: sangat setuju.

Desirable financial behavior dengan 5 item pertanyaan dan skala yang digunakan 1: sangat tidak setuju sampai 5: sangat setuju.

Perceived financial capability dengan 4 item pertanyaan dan skala yang digunakan 1: sangat tidak setuju sampai 5: sangat setuju.

Tabel 1. Aspek Demografi

\begin{tabular}{|c|l|l|l|}
\hline $\begin{array}{c}\text { Faktor } \\
\text { Demografi }\end{array}$ & \multicolumn{1}{|c|}{ Klasifikasi } & \multicolumn{1}{c|}{$\begin{array}{c}\text { Jumlah } \\
\text { Responden }\end{array}$} & \% \\
\hline \multirow{5}{*}{ Usia } & $15-20$ tahun & 147 & 37 \\
\cline { 2 - 4 } & $21-26$ tahun & 221 & 55,25 \\
\cline { 2 - 4 } & $27-32$ tahun & 15 & 3,5 \\
\cline { 2 - 4 } & $33-38$ tahun & 6 & 1,5 \\
\cline { 2 - 4 } & $39-43$ tahun & 4 & 1 \\
\cline { 2 - 4 } & $44-49$ tahun & 5 & 1,25 \\
\cline { 2 - 4 } & 50-55 tahun & 2 & 0,5 \\
\hline \multirow{5}{*}{ Jenis Kelamin } & Perempuan & 265 & 33,75 \\
\cline { 2 - 4 } & Laki-laki & 135 & 11,5 \\
\hline \multirow{3}{*}{ Pendidikan } & D1/D2/D3 & 46 & 86 \\
\cline { 2 - 4 } & S1 & 344 & 2,5 \\
\cline { 2 - 4 } & S2/S3 & 10 & \\
\hline
\end{tabular}


Lanjutan Tabel 1. Aspek Demografi

\begin{tabular}{|c|c|c|c|}
\hline $\begin{array}{c}\text { Faktor } \\
\text { Demografi }\end{array}$ & Klasifikasi & $\begin{array}{c}\text { Jumlah } \\
\text { Responden }\end{array}$ & \% \\
\hline \multirow{2}{*}{$\begin{array}{c}\text { Status } \\
\text { pernikahan }\end{array}$} & Menikah & 32 & 8 \\
\cline { 2 - 4 } Tanggungan & Belum Menikah & 368 & 92 \\
\cline { 2 - 4 } Anak & Ya & 31 & 7,75 \\
\hline
\end{tabular}

Sumber : Data Primer, diolah (2020)

Dari hasil data yang diperoleh kelompok usia 21-26 tahun mempunyai persentase terbesar yaitu 55,25 persen, untuk persentase terkecil terdapat pada kelompok usia 50-55 tahun yaitu 0,5 persen. Untuk jenis kelamin diperoleh data sebanyak 66,25 persen adalah perempuan dan 33,75 persen adalah laki-laki. Pendidikan paling banyak yaitu S1 dengan 86 persen, kemudian persentase terkeceil yaitu S2/S3 dengan nilai 2,5 persen. Sebanyak 92 persen responden menyatakan belum menikah dan 92,25 persen tidak atau belum memiliki anak dan sisanya berstatus menikah dan memiliki anak.

\section{HASIL PENELITIAN DAN PEMBAHASAN Uji Normalitas}

Uji normalitas dilakukan untuk melihat apakah data memiliki distribusi yang normal atau tidak. Uji normalitas dalam penelitian ini dilakukan melalui uji statistik non-parametrik, Kolmogorov-Smirnov, dimana data berdistribusi normal akan memiliki nilai Asymp.sig > nilai signifikansi $(0,05)$. Berikut hasil uji normalitas:

Tabel 2. Hasil Uji Normalitas-Kolmogorov Smirnov

One-Sample Kolmogorov-Smirnov Test

$\mathrm{N}$

Normal

Parameters ${ }^{\mathrm{a}, \mathrm{b}}$

Most Extreme

Differences

Test Statistic

Asymp. Sig. (2-tailed)
Unstandardized Residual

400

Mean $\quad .0000000$

Std. Deviation $\quad 2.07868025$

Absolute $\quad .045$

Positive $\quad .024$

Negative $\quad-.045$

.045

$.055^{\mathrm{c}}$

Sumber : Hasil Penelitian, diolah (2020)

Berdasarkan tabel 2 maka dapat disimpulkan bahwa data telah berdistribusi normal karena nilai Asymp. Sig. (2-tailed) yaitu 0,055 lebih besar dari 0,05.

\section{Uji Multikolinieritas}

Tabel 3. Hasil Uji Multikolinearitas

\begin{tabular}{|l|l|l|}
\hline \multirow{2}{*}{ Model } & \multicolumn{2}{|l|}{ Collinearity StatisticS } \\
\cline { 2 - 3 } & Tolerance & VIF \\
\hline $\begin{array}{l}\text { Pendidikan } \\
\text { Keuangan }\end{array}$ &, 984 & 1,017 \\
\hline
\end{tabular}




\begin{tabular}{|l|l|l|}
\hline $\begin{array}{l}\text { Kemampuan } \\
\text { Keuangan }\end{array}$ &, 984 & 1,017 \\
\hline
\end{tabular}

Sumber : Hasil Penelitian, diolah (2020)

Berdasarkan data pada tabel 3 dapat dilihat bahwa nilai tolerance variabel pendidikan keuangan dan kemampuan keuangan sebesar 0,984 dengan nilai VIF sebesar 1,017, sehingga nilai tolerance lebih dari 0,01 dan nilai VIF kurang dari 10. Maka, dapat disimpulkan bahwa tidak terdapat multikolinearitas pada data penelitian.

\section{Analisis Korelasi Pearson}

Analisis korelasi pearson digunakan untuk mengethaui hubungan variabel pendidikan keuangan, kemampuan keuangan dan kepuasan keuangan.

Tabel 4. Hasil Analisis Korelasi Pearson

\begin{tabular}{|c|c|c|c|c|}
\hline \multicolumn{5}{|l|}{ Correlations } \\
\hline & & $\begin{array}{l}\text { Pendidikan } \\
\text { Keuangan }\end{array}$ & $\begin{array}{l}\text { Kepuasan } \\
\text { Keuangan }\end{array}$ & $\begin{array}{l}\text { Kemampua } \\
\text { n Keuangan }\end{array}$ \\
\hline \multirow[t]{3}{*}{$\begin{array}{l}\text { Pendidikan } \\
\text { Keuangan }\end{array}$} & $\begin{array}{l}\text { Pearson } \\
\text { Correlation }\end{array}$ & 1 & $.278^{* *}$ & $.128^{*}$ \\
\hline & Sig. (2-tailed) & & .000 & .010 \\
\hline & $\mathrm{N}$ & 400 & 400 & 400 \\
\hline \multirow[t]{3}{*}{$\begin{array}{l}\text { Kepuasan } \\
\text { Keuangan }\end{array}$} & $\begin{array}{l}\text { Pearson } \\
\text { Correlation }\end{array}$ & $.278^{* * *}$ & 1 & $.523^{* *}$ \\
\hline & Sig. (2-tailed) & .000 & & .000 \\
\hline & $\mathrm{N}$ & 400 & 400 & 400 \\
\hline \multirow[t]{3}{*}{$\begin{array}{l}\text { Kemampuan } \\
\text { Keuangan }\end{array}$} & $\begin{array}{l}\text { Pearson } \\
\text { Correlation }\end{array}$ & $.128^{*}$ & $.523^{* *}$ & 1 \\
\hline & Sig. (2-tailed) & .010 & .000 & \\
\hline & $\mathrm{N}$ & 400 & 400 & 400 \\
\hline
\end{tabular}

Sumber : Hasil Penelitian, diolah (2020)

Berdasarkan hasil tabel 4 dapat disimpulkan sebagai berikut:

Nilai $r$ korelasi antara variabel pendidikan keuangan dengan kemampuan keuangan yaitu sebesar 0,128 dengan nilai sig. $<0,05$, artinya kedua variabel memiliki korelasi positif dengan tingkat hubungan yang termasuk dalam kategori sangat rendah. Hal ini memiliki arti bahwa pendidikan keuangan tidak terlalu berpengaruh terhadap kemampuan keuangan.

Nilai korelasi antara pendidikan keuangan dengan kepuasan keuangan yaitu sebesar 0,278 dengan nilai sig. $<0,05$, artinya bahwa kedua variabel memiliki korelasi positif dengan tingkat hubungan kategori rendah. Hal ini berarti bahwa pendidikan keuangan tidak terlalu berpengaruh terhadap kepuasan keuangan.

Nilai korelasi antara kemampuan keuangan dengan kepuasan keuangan sebesar 0,523 dengan sig. $<0,05$, artinya bahwa kedua variabel memiliki korelasi positif dengan tingkat hubungan dalam kategori sedang. Hal ini memiliki arti bahwa kepuasan keuangan berpengaruh terhadap kepuasan keuangan.

\section{Analisis Mediasi}


Adanya korelasi antar variabel maka penelitian ini memenuhi syarat mediasi menurut Baron dan Kenny yaitu variabel independen diasumsikan menyebabkan mediator kedua variabel tersebut harus berkorelasi.

Tabel 5. Pengaruh Mediasi Kemampuan Keuangan Pada Hubungan Anatara Pendidikan Keuangan Dan Kepuasan Keuangan

\begin{tabular}{|l|l|l|l|l|l|l|l|l|}
\hline & \multicolumn{4}{|l|}{ Kemampuan Keuangan } & \multicolumn{3}{l|}{ Kepuasan Keuangan } \\
\cline { 2 - 9 } & $\mathrm{T}$ & SE & Coeff & $\mathrm{P}$ & $\mathrm{T}$ & SE & Coeff & $\mathrm{P}$ \\
\hline $\begin{array}{l}\text { Pendidikan } \\
\text { Keuangan }\end{array}$ & 2,582 & $\begin{array}{l}0,91 \\
3\end{array}$ & 2,358 & 0,010 & 5,145 & 0,225 & 1,158 & 0,000 \\
\hline $\begin{array}{l}\text { Kemampuan } \\
\text { Keuangan }\end{array}$ & & & & & 11,866 & 0,012 & $\begin{array}{l}0,145 \\
5\end{array}$ & 0,000 \\
\hline
\end{tabular}

Sumber : Hasil Penelitian, diolah (2020).

Berdasarkan tabel 5 dapat dilihat hasil hubungan sebagai berikut:

a. Koefisian nilai pendidikan keuangan terhadap kemampuan keuangan yaitu sebesar 2,358 bernilai positif dengan $p$-value $<0,05$. Hal ini mempunyai arti bahwa terdapat hubungan yang signifikan antara pendidikan keuangan dan kemampuan keuangan.

b. Koefisian nilai pendidikan keuangan terhadap kepuasan keuangan yaitu sebesar 1,158 bernilai positif dengan $p$-value $<0,05$, yang berarti bahwa terdapat hubungan yang signifikan antara pendikan keuangan dan kepuasan.

c. Koefisian nilai kemampuan keuangan dengan kepuasan keuangan yaitu sebesar 0,1455 bernilai positif dengan $p$-value $<0,05$, yang mempunyai arti bahwa terdapat hubungan yang signifikan antar kemampuan keuangan dan kepuasan keuangan.

Mediasi pada penelitian ini termasuk dalam bentuk parsial atau mediasi sebagian karena apabila kemampuan keuangan dihilangkan, maka variabel pendidikan keuangan masih dapat mempengaruhi variabel kepuasan keuangan. Analisis selanjutnya yaitu menggunakan uji Sobel $Z$ test untuk mengetahui pengaruh secara tidak langsung antara pendidikan keuangan dan kepuasan keuangan melalui variabel mediasi kemampuan keuangan. Hasil perhitungan Sobel $Z$ test dapat dilihat pada tabel 6 berikut:

Tabel 6. Hasil Sobel $Z$ test

\begin{tabular}{|l|l|l|}
\hline \multicolumn{3}{|c|}{ Normal theory test for indirect effect } \\
\hline$S E$ & $Z$ & $P$ \\
\hline 0,315 & 2,526 & 0,012 \\
\hline
\end{tabular}

Sumber : Hasil Penelitian, diolah (2020)

Dari hasil Sobel z test dapat diketahui bahwa pengaruh tidak langsung anatara pendidikan keuangan dengan kepuasan keuangan melalui kemampuan keuanagns sebagai variabel mediasi yaitu sebesar 2,526. Untuk mengetahui pengaruh langsung variabel pendidikan keuangan terhadap kepuasan keuangan dapat dilihat pada tabel 7 berikut:

Tabel 7. Hasil Pengaruh Langsung $X$ ke $Y$

\begin{tabular}{|l|l|l|l|}
\hline Effect & SE & T & P \\
\hline 1,1584 & 0,2251 & 5,1453 & 0,000 \\
\hline
\end{tabular}

Sumber : Hasil Penelitian, diolah (2020) 
Pada tabel 6 dapat diketahui bahwa hasil Sobel Z test yaitu sebesar 2,525> nilai mutlak 1,96 dengan nilai signifikansi 5\%, dan $p$-value 0,012 $<0,05$ maka membuktikan bahwa kemampuan keuangan mampu memediasi hubungan pendidikan keuangan terhadap kepuasan keuangan. Berdasarkan semua pengujian yang telah dilakukan bahwa kemampuan keuangan merupakan variabel mediasi dari pengaruh antara variabel pendidikan keuangan dan variabel kepuasan keuangan. Pada tabel 4 dapat diketahui bahwa terjadi korelasi antar variabel. Hal ini mendukung untuk terjadinya mediasi dalam penelitian ini. Tabel 4 dapat dilihat bahwa terdapat hubungan yang signifikan antara pendidikan keuangan, kemampuan keuangan, dan kepuasan keuangan. Tabel 5 mengenai pengaruh pendidikan keuangan terhadap kemampuan keuangan menunjukkan nilai yang signifikan, hal ini karena nilai koefisien positif 2,358 dengan $p$-value $<0,05$ yaitu 0,0102. Sehingga $\mathrm{H} 1$ : pendidikan keuangan memiliki efek yang signifikan terhadap kemampuan keuangan diterima. Hasil selanjutnya pada pengaruh kemampuan keuangan terhadap kepuasan keuangan juga menunjukkan hasil yang signifikan, dikarenakan nilai koefisien positif 0,1455 dengan nilai signifikansi $<0,05$ yaitu 0,000 . Sehingga H1: kemampuan keuangan memiliki pengaruh yang signifikan terhadap kepuasan keuangan diterima.

Pada nilai koefisian pendidikan keuangan terhadap kemampuan keuangan model 1 sebesar 2,358 dengan $p$-value $<0,05$ dan model 3 sebesar 0,1455 dengan $p$ value $<0,05$, hal ini menunjukkan bahwa terjadi mediasi. Selanjutnya pada tabel 5 didapatkan hasil sobel $\mathrm{Z}$ test menunjukkan bahwa $\mathrm{Z}$ value sebesar 2,526 dan $p$-value sebesar 0,0115, hasil ini menunjukkan bahwa pengaruh tidak lansgung pendidikan keuangan terhadap kepuasan keuangan yang melalui kemampuan keuangan signifikan karena nilai $\mathrm{Z}$ lebih besar dari titik kritis dengan nilai signifikansi 5\% sebesar 1,96 atau 2,526>1,96. Hasil dari pengolaahn data pada penelitian ini membuktikan bahwa variabel kemampuan keuangan secaar parsial memediasi pengaruh pendidikan keuangan terhadap kepuasan keuangan pada usia produktif di Daerah Istimewa Yogyakarta. Sehingga H3: pengaruh pendidikan keuangan terhadap kepuasan keuangan lebih tinggi jika diteliti dengan kemampuan keuangan dibandingkan tanpa kemampuan keuangan sebagai variabel mediasi diterima.

\section{KESIMPULAN DAN SARAN \\ Kesimpulan}

Berdasarkan pengolahan data dan analisis yang telah dilakukan, maka dari itu peniliti dapat mengambil kesimpulan sebagai berikut:

1. Pendidikan keuangan memiliki pengaruh yang signifikan terhadap kemampuan keuangan

2. Kemampuan keuangan memiliki pengaruh yang signifikan terhadap kepuasan keuangan

3. Pengaruh pendidikan keuangan pada kepuasan keuangan lebih tinggi jika diteliti dengan kemampuan keuangan dibandingkan diteliti tanpa kemampuan keuangan sebagai variabel mediasi. 


\section{Saran}

Pemerintah Daerah Istimewa Yogyakarta perlu meningkatkan sosialisasi kepada masyarakat mengenai produk keuangan, peningkatan kemampuan keuangan yang ada melalui lembaga-lembaga keuangan secara berkala agar produk keuangan, jasa keuangan yang ada dapat dimengerti masyarakat dengan baik, seperti mengenai kartu kredit, investasi dan giro. Program pemerintah ini dapat di sosialisasikan melalui zona terkecil atau kelompok terkecil dalam masyarakat seperti dari rukun tangga sampai ke tingkat nasional. Pemerintah juga harus memberikan penyuluhan kepada masyarakat melalui lembaga pendidikan tentang pentingnya pengetahuan tentang keuangan yang akan berpengaruh terhadap perilaku seseorang dalam pengambilan keputusan keuangan dengan baik. Penduduk usia produktif di Daerah Istimewa Yogyakarta harus lebih meningkatkan pendidikan keuangan melalui kemampuan keuangan agar tercipta kepuasan keuangan. Dimana hal tersebut harus dilakukan dalam lingkup ekonomi terkecil mulai dari diri sendiri atau di lingkungan keluarga.

\section{DAFTAR PUSTAKA}

Ahmad, K. A., Hassan, R., \& Idris, F. 2017. Influence of Financial Literacy on Financial Satisfaction with Financial Behavior as Moderating Variable. Asian Journal of Technical Vocational Education And Training (AJTVET), 2, 1-9.

Anwar, M. 2019. Dasar-Dasar Manajemen Keuangan Perusahaan. Jakarta: Kencana.

BI. 2015. Kajian Stabilitas Keuangan. Jakarta: Bank Indonesia Departemen Kebijakan Makroprudensial.

BPS. 2018. Jumlah Penduduk Menurut Kelompok Umur dan Jenis Kelamin di Yogyakarta 2018. DI Yogyakarta: Badan Pusat Statistik Provinsi DI Yogyakarta.

Chandra, J. W., \& Memarista, G. 2015. Faktor-Faktor yang Mempengaruhi Financial Satisfaction pada Mahasiswa Universitas Kristen Petra. Finesta, 3(2), 1-6.

Cobb-Clark, D. A., Sonja, K. C., \& Mathias, S. G. 2016. Locus of control and savings. Journal of Banking \& Finance, 73, 113-130.

Cohen, M., \& Nelson, C. 2011. Financial Literacy : A Step For Clients Toward Financial Inclusion. Valladolid: Global Microcredit Summit 2011.

Deil, S. A. 2018. Liputan6.com. Retrieved from Riset: Milenial Rela Terlilit Utang Demi Gaya Hidup dan Pergaulan: https://www.liputan6.com/bisnis/read/3469682/riset-milenial-rela-terlilit-utangdemi-gaya-hidup-dan-pergaulan

Fahmi, I. 2014. Pengantar Manajemen Keuangan Teori dan Soal Jawab. Bandung: Alvabeta.

Hakim, F. A., Sunarti, E., \& Herawati, T. 2014. Manajemen Keuangan dan Kepuasan Keuangan Istri pada Keluarga dengan Suami Istri Bekerja. Jurnal Ilmu Keluarga dan Konsumen, 7(3), 174-182.

Halim, Y. K., \& Astuti, D. 2015. Financial Stressors, Financial Behavior, Risk Tolerance, Financial Solvency, Financial Knowledge dan Kepuasan Finansial. Jurnal Finesta, 3(1), 19-23.

Hassan, R., Ahmad, K. A., \& Idris, F. 2019. Relationship Between Financial Literacy and Financial Practices on Financial Satisfaction: Exploring Gender. Journal of Life Long Learning, 3(1), 1-9. 
Herawati, N. T. 2015. Kontribusi Pembelajaran di Perguruan Tinggi dan Literasi Keuangan Terhadap Perilaku Keuangan Mahasiswa. Jurnal Pendidikan dan Pengajaran, 1-3(48), 60-70.

Indrawati. 2015. Metedologi Penelitian Manajemen dan Bisnis : Konvergensi Teknologi Komunikasi dan Informasi. Bandung: Refika Aditama.

Kompasiana. 2019. Kompasiana,com. Retrieved from Pentingnya Pendidikan Finansial Bagi Anak: https://www.kompasiana.com/azhargood/5ddf4b8c097f365ef9756992/pentingnyapendidikan-finansial-bagi-anak?page=all.

McMenamin, J. 2012. Financial Management : An Introduction. Oxon: Routledge.

Mehwish, Z., \& Muhammad, B. 2016. Financial wellbeing is the goal of financial literacy. Research Journal of Finance and Accounting, 11(17).

Neolaka, A. 2014. Metode Penelitian dan Statistik. Bandung: Rosda Karya.

OJK. 2017. Strategi Nasional Literasi Keuangan Indonesia (Revisit 2017). Jakarta: Otoritas Jasa Keuangan.

Primadhyta, S. 2018. cnnindonesia.com. Retrieved from Siasat Hindari Jeratan Utang Kartu Kredit: https://www.cnnindonesia.com/ekonomi/20180309205049-83281874/siasat-hindari-jeratan-utang-kartu-kredit

Rapih, S. 2016. Pendidikan Literasi Keuangan Pada Anak: Apa dan Bagaimana? Scholaria, 6(2), 14-28.

Sari, F. M. 2019. Liputan6.com. Retrieved from Jangan Sepelekan, Ketahui Pentingnya Edukasi Keuangan Sejak Dini: https://www.liputan6.com/bisnis/read/4063975/jangan-sepelekan-ketahuipentingnya-edukasi-keuangan-sejak-dini

Sari, P. P., \& Septyarini, E. 2018. Pengaruh Financial Technology Terhadap Kepuasan Keuangan (Studi kasus pada Pedagang di Pasar Beringharjo Yogyakarta). Jurnal UMKM Dewantara, 1(1), 20-28.

Septiana, A. 2017. Model Literasi Keuangan Pondok Pesantren Madura. Jurnal Hukum dan Bisnis Syariah, 4(1), 35-45.

Sepulsa.com. 2019. Sepulsa.com. Retrieved from Kerugian dan Dampak Buruk Penggunaan Kartu Kredit: https://www.sepulsa.com/blog/kerugian-dan-dampakburuk-penggunaan-kartu-kredit

Sigo, M. R., Hariani, L. S., \& Walipah. 2018. Pengaruh Literasi Keuangan Kecerdasan Spiritual. Jurnal Riset Pendidikan Ekonomi, 3(1), 1-9.

Sujarweni, V. W. 2017. Manajemen Keuangan: Teori Aplikasi dan Hasil Penelitian. Yogyakarta: Pustaka Baru Press.

Yoshino, N., Morgan, P. J., \& Wignaraja, G. 2015. Financial education in Asia: Assessment and recommendations. Tokyo: Asian Development Bank Institute (ADBI): ADBI Working Paper 534.

Yushita, A. N. 2017. Pentingnya Literasi Keuangan Bagi Pengelolaan Keuangan Pribadi. Jurnal Nominal, 6(1), 11.

Xiao, J. J., \& O'Neill, B. 2016. Consumer Financial Education and Financial Capability. International Journal of Consumer Studies, 40(6), 712-721. 
Xiao, J. J., Chen, C., \& Chen, F. 2014. Consumer Financial Capability and Financial Satisfaction. An International and Interdisciplinary Journal for Quality of Life Measurement, Vol 118 Issue :1, pp 415-432.

Xiao, J., \& Porto, N. 2017. Financial Education and Financial Satisfaction : Financial Literacy, Behavior, and Capability as Mediators. International Journal of Bank Marketing, 35(5), 805-817. 